\title{
Lembar Kerja Peserta Didik (LKPD) Berbasis High Order Thingking Skills (HOTS) pada Pembelajaran Tematik
}

\section{Dira Putri Utami1*, Febrina Dafit²

\author{
1,2 Pendidikan Guru Sekolah Dasar, Universitas Islam Riau, Pekanbaru, Indonesia
}

\section{ART ICLE IN F O}

Article history:

Received October 19, 2021

Revised October 20, 2021

Accepted November 12, 2021

Available online December 25, 2021

Kata Kunci:

LKPD, HOTS, Pembelajaran

Tematik, SD

Keywords:

LKPD, HOTS, Thematic Learning, Elementary School

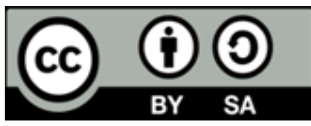

This is an open access article under the CC BY-SA license.

Copyright (@) 2021 by Author. Published by Universitas Pendidikan Ganesha.

\begin{abstract}
A B S T R A K
Masih banyak siswa yang kesulitan memecahkan masalah yang diminta dan berdampak pada hasil nilai yang diperoleh oleh peserta didik. Maka dari itu penelitian ini bertujuan untuk mengembangkan bahan ajar LKPD (Lembar Kerja Peserta Didik) berbasis HOTS (High Order Thingking Skills) pada Tema 1 Organ Gerak Hewan dan Manusia Subtema 3 Manfaat Lingkungan. Jenis penelitian ini yaitu pengembangan dengan menggunakan model ADDIE yang disederhanakan menjadi empat tahapan yaitu (Analysis, Design, Development, Impementasi). Instrumen pengumpulan data yang digunakan berupa angket yang diberikan kepada ahli desain, ahli materi, ahli bahasa untuk menguji kelayakan, serta respon guru dan peserta didik untuk menguji kemenarikan. Jenis data yang diperoleh dari hasil penelitian adalah data kualitatif yang dianalisis menggunakan data kuantitatif berupa data angka dan diinterpretasikan dengan pedoman kriteria kategori penilaian untuk menentukan kualitas produk. Hasil dari penelitian ini, menghasilkan produk LKPD yang dapat digunakan pada jenjang SD sebagai bahan ajar atau pegangan buku ajar peserta didik yang telah memenuhi kriteria sangat baik dengan skor rata-rata dari ahli desain $90 \%$ ahli materi $88 \%$ dan ahli bahasa $90 \%$ dengan kategori sangat layak serta respon yang diberikan oleh pendidik 99\% dengan kategori sangat menarik, dan dilakukan uji coba skala kecil $84 \%$ dengan kategori sangat menarik. Bahan ajar LKPD (Lembar Kerja Peserta Didik) sudah layak digunakan dalam proses pembelajaran.
\end{abstract}

A B S T RA CT

There are still many students who have difficulty solving the problems asked and impacts students' results. Therefore, this study aims to develop teaching materials for LKPD (Student Worksheets) based on HOTS (High Order Thinking Skills) on Theme 1 Animal and Human Movement Organs Subtheme 3 Environmental Benefits. This type of research is developed using the ADDIE model, which is simplified into four stages, namely (Analysis, Design, Development, Implementation). The data collection instrument used was in the form of a questionnaire given to design experts, material experts, linguists to test the feasibility, and teacher and student responses to test attractiveness. The type of data obtained from the study results is qualitative data which is analyzed using quantitative data in the form of numerical data and is interpreted with guidelines for assessment category criteria to determine product quality. The results of this study produce LKPD products that can be used at the elementary level as teaching materials or student textbooks that have met the criteria very well with an average score of $90 \%$ design experts, $88 \%$ material experts, and $90 \%$ of linguists in the very appropriate category and $99 \%$ of the responses given by educators in the exciting category, and a small-scale trial of $84 \%$ with the exciting category. LKPD teaching materials are suitable for use in the learning process.

\section{PENDAHULUAN}

Pendidikan merupakan sebuah aktifitas yang memiliki maksud atau tujuan tertentu yang diarahkan untuk mengembangkan potensi yang dimiliki manusia (Bui \& Do Van Dung, 2019; Lewis \& Ponzio, 2016; Tempelaar, 2019). Pendidikan mempunyai pengertian proses pengubahan sikap dan tata laku seseorang atau kelompok orang dalam usaha mendewasakan manusia melalui upaya pengajaran dan 
latihan, proses perbuatan, cara mendidik (Hendawi \& Nosair, 2020; Hidayat \& Andriani, 2020; Kidd et al., 2020; Sulistiono, 2014). Pendidikan sebagai daya upaya untuk memajukan budi pekerti, pikiran serta jasmani anak, agar dapat memajukan kesempurnaan hidup yaitu hidup dan menghidupkan anak yang selaras dengan alam dan masyarakatnya. Untuk menghidupkan anak agar selaras dengan alam dan masyarakat, peran yang dilakukan guru sangatlah penting dalam proses pembelajaran (Kusumaningtyas \& Setyawafi, 2015; Supriyanto et al., 2020; Uerz et al., 2018). Dalam hal ini guru berperan untuk menciptakan sebuah pembelajaran yang menarik untuk siswa. Proses pembelajaran merupakan kegiatan utama dalam lingkungan pendidikan, karena dengan adanya proses pembelajaran maka dapat diartikan terjadinya interaksi dan pemanfaatan berbagai sumber daya yang ada baik dari potensi yang bersumber dari dalam diri maupun potensi yang ada di luar diri untuk mencapai tujuan belajar tertentu (Amali et al., 2020; Khamzawi \& Wiyono, 2015; Ruengtam, 2013; Rusydiyah et al., 2021). Pembelajaran adalah salah satu aktifitas interaksi edukatif antara guru dengan siswa yang didasari oleh adanya tujuan baik berupa pengetahuan, sikap maupun ketrampilan (Cintia et al., 2018; Jing et al., 2020; Saifullah, 2018). Sedangkan kegiatan pembelajaran adalah rangkaian kegiatan yang dirancang untuk memberikan pengalaman belajar yang melibatkan proses mental dan fisik melalui interaksi antara siswa, siswa dengan lingkungan, dan sumber belajar lainnya dalam rangka mencapai kompotensi (Dewi, 2017; Junedi et al., 2020; Nikmah et al., 2019). Pembelajaran juga memerlukan sarana pendukung seperti bahan ajar ataupun media pembelajaran menarik yang dapat meningkatkan motivasi belajar siswa (Ningsih \& Mahyuddin, 2021; Silalahi, 2020; Susanti et al., 2020).

Namun permasalahan yang terjadi saat ini yaitu masih banyak guru yang kurang menerapkan bahan ajar inovatif yang dapat merangsang siswa dalam belajar (Andani, 2020; Pramana et al., 2020; Silalahi, 2020). Permasalahan ini juga terjadi di salah satu sekolah dasar. Berdasarkan hasil wawancara dengan guru kelas V SD Negeri 174 Pekanbaru guru menyatakan bahwa LKPD (Lembar Kegiatan Peserta Didik) disekolah tersebut dinamakan LKS (Lembar Kerja Siswa) digunakan pada saat guru tidak hadir kesekolah ataupun dalam proses rapat guru hanya memberikan tugas berupa LKS (Lembar Kerja Siswa). Berdasarkan analisis yang dilakukan terhadap LKS yang digunakan guru dalam proses pembelajaran pertama yaitu materi yang ada didalam LKS sangatlah minim. Hal ini yang membuat siswa kesulitan untuk memahami materi pembelajaran. Kedua, yaitu akibat dari materi yang terlalu minim sehingga siswa kesulitan untuk menyelesaikan suatu persoalan yang akan dipecahkan oleh siswa. Ketiga, yaitu dalam menyelesaikan suatu persoalan yang akan dipecahkan oleh siswa, belum terlihat adanya arahan yang harus dilakukan oleh siswa. Keempat yaitu LKS yang diajukan kepada siswa belum menarik perhatian siswa karena warna yang ditampilkan masi minim seperti warna abu-abu dan hitam. Dari hasil nilai belajar siswa ketika mengerjakan LKS ditemukan bahwa dari 32 orang siswa hanya 12 orang siswa yang tuntas dalam mengerjakan LKS.

Bahan ajar yang digunakan guru dan siswa dalm proses pembelajaran, lengkap dengan pembahasan materi ataupun latihan-latihan yang akan dipecahkan asalahnya oleh siswa yaitu LKS yang pada saat ini berupah posisi nama yaitu LKPD (Nurliawaty et al., 2017; Pentury et al., 2019). LKPD merupakan materi ajar yang dikemas sedemikian rupa sehingga siswa dapat mempelajari materi tersebut secara mandiri, sehingga siswa jadi lebih aktif untuk memecahkan masalah yang ada melalui kegiatan diskusi kelompok, praktikum, dan kegiatan menjawab permasalahan yang berhubungan dengan kehidupan sehari-hari (Marshel \& Ratnawulan, 2020; Yuliani et al., 2018; Yustina \& Kapsin, 2017). Hal ini menjadikan siswa akan lebih tertantang dalam proses kegiatan pembelajaran yang hanya sekedar satu arah saja (Indrianingrum et al., 2018; Suryawati et al., 2020). Kegiatan memecahkan masalah yang ada dalam LKPD (Lembar Kegiatan Peserta Didik) tersebut yang nantinya dapat berimbas pada peningkatan cara berpikirnya termasuk berpikir kritis (Dini Rahma Diani, Nurhayati, 2019; Yulianto et al., 2017; Yustina \& Kapsin, 2017). Pembelajaran yang tidak menyenangkan berimbas kepada nilai yang akan diperoleh oleh siswa sehingga mengakibatkan rendahnya nilai siswa dan tidak tercapainya rencana yang telah ditetapkan oleh guru (Husnah, 2017; Trianggono, 2017).

Hal ini yang menyebabkan diperlukan sebuah alternatif yang dirasa efektif dan iovatif dalam mengatasi hal tersebut. Solusi yang dimaksud yaitu mengembangkan LKPD yang inovatif. Dalam proses pembelajaran, pada saat ini Indonesia menerapkan kurikulum 2013. Kurikulum 2013 yang diterapan pada saat sekarang dirancang sebagai peningkatan kemampuan peserta didik dalam berpikir kritis dan kreatif (Akib et al., 2020; Astiningtyas, 2018; Suantara et al., 2019). Berpikir kritis dan kreatif merupakan bagian dari kemampuan berpikir tingkat tinggi (HOTS) (Putri et al., 2013; Sari et al., 2016). Kemampuan berpikir tingkat tinggi sangat diperlukan siswa dalam menghadapi era pendidikan di masa yang akan dating (Pratama \& Retnawati, 2018; Putranta \& Supahar, 2019; Sagala \& Andriani, 2019). Kemampuan berpikir tingkat tinggi adalah proses berpikir kompleks dalam menguraikan materi, membuat kesimpulan, membangun representasi, menganalisis, dan membangun hubungan dengan melibatkan aktivitas mental yang paling besar (Andoko, 2020; Ichsan et al., 2019; Nurmala \& Mucti, 2019). Temuan penelitian 
sebelumnya juga menyatakan bahwa siswa yang memiliki kemampuan berpikir tingkat tinggi (HOTS) akan meningkatkan hasil belajar siswa (Afrita \& Darussyamsu, 2020; Prastikawati et al., 2021). Temuan penelitian lainnya juga menyatakan bahwa LKPD yang inovatif akan meningkatkan semangat belajar siswa (Marshel \& Ratnawulan, 2020; Nurliawaty et al., 2017; Pentury et al., 2019). Dapat disimpulkan bahwa LKPD berbasis HOTS dapat membantu meningkatkan semangat dan hasil belajar siswa. Belum adanya kajian mengenai LKPD berbasis HOTS untuk pembelajaran Tematik. Tujuan penelitian ini yaitu untuk mengembangkan bahan ajar LKPD (Lembar Kerja Peserta Didik) berbasis HOTS (High Order Thingking Skills) pada Tema 1 Organ Gerak Hewan dan Manusia Subtema 3 Manfaat Lingkungan. Diharapkan LKPD berbasis HOTS dapat membantu siswa dalam belajar.

\section{METODE}

Dalam penelitian ini, jenis penelitian yang digunakan yaitu penelitian pengembangan. Untuk mengembangakan bahan ajar digunakan model ADDIE. Hal ini disebabkan karena model desain pembelajaran yang sifatnya lebih generik. Adapun lima tahapan model ADDIE yaitu analisis, desain, pengembangan, implementasi dan evaluasi (Pramana et al., 2020; Wulandari et al., 2020). Tahapan model ADDIE untuk membangan LKPD (Lembar Kerja Peserta Didik) berbasis HOTS berbasis ini dimodifikasi menjadi empat tahapan yaitu analisis, design, developmen, dan implementasi. Penelitian ini mengambil empat tahapan dikarenakan dari kondisi (Covid 19) pada saat ini tidak memungkinkan sampai tahap evaluasi. Lokasi penelitian ini dilaksanakan di Sekolah Dasar untuk kelas V. Produk yang telah dikembangkan akan dinilai oleh dua orang ahli media, dua orang ahli materi, dua orang ahli bahasa, satu orang wali kelas V. Subjek uji coba berjumlah sepuluh orang peserta didik. Metode yang digunakan untuk mengumpulkan data yaitu observasi, wawancara, dan kuesioner. Instrument yang digunakan untuk mengumpulkan data yaitu kuesioner. Angket kebutuhan dalam pengembangan produk yang akan dianalisis menggunakan data deskriptif kualitatif dengan cara penyajian data melalui beberapa pertanyaan sesuai dengan keadaan dan kebutuhan yang ada pada saat penelitian. Untuk memperoleh hasil penelitian ini menggunakan angket validasi yang akan diberikan kepada ahli materi, bahasa, serta desain dan guru, pada penelitian dan pengembangan ini menggunakan skala Likert dan pengukuran yang merujuk pada buku karangan (Ridwan, 2016). Untuk menentukan kriteria dalam menentukan hasil dari validasi disajikan pada Tabel 1 .

Tabel 1. Kriteria menentukan Hasil Validasi

\begin{tabular}{cc}
\hline Kriteria & Range persentase \\
\hline Tidak layak & $0 \%-20 \%$ \\
Kurang layak & $21 \%-40 \%$ \\
Sedang & $41 \%-60 \%$ \\
Layak & $61 \%-80 \%$ \\
Sangat layak & $81 \%-100 \%$ \\
\hline
\end{tabular}

(Ridwan, 2016)

Dalam memperoleh hasil penelitian ini menggunakan angket tanggapan digunakan untuk mengumpulkan data mengenai tanggapan peserta didik terhadap bahan ajar LKPD (Lembar Kerja Peserta Didik) berbasis HOTS yang dikembangkan dengan menggunakan Skala Guttman. Skala Guttman merupakan skala yang digunakan untuk jawaban yang bersifat jelas (tegas) dan konsisten. Misalnya: Yakin-Tidak Yakin; Ya-Tidak; Benar-Salah; Positif-Negatif; Penah-Belum Pernah; Setuju-Tidak Setuju; dan lain sebagaianya (Ridwan, 2016).

\section{HASIL DAN PEMBAHASAN}

Hasil

Tahap pertama yaitu Analisis. Analisis dilakukan untuk mendapatkan informasi dalam mengembangkan bahan LKPD berbasis HOTS sesuai kebutuhan peserta didik dalam proses pembelajaran. Penelitian ini dikembangkan dari masalah yang muncul pada saat proses pembelajaran berlangsung, guru hanya LKPD berbasis HOTS pada tidak hadir kesekolah dan rapat maka dari itu peserta didik kesulitan untuk memecahkan masalah yang diminta. Siswa menemukan kesulitan untuk memecahkan masalah yang diminta pada LKPD sehingga berdampak pada hasil nilai yang diperoleh oleh peserta didik. Hal ini yang menyebabkan dikembangkannya LKPD berbasis HOTS dikarenakan memunculkan semangat peserta didik untuk belajar mandiri dan bisa menyelesaikan suatu masalah yang mucul. Materi pembejaran dianalisis 
pada buku siswa 1 “Organ Gerak Hewan dan Manusia” Sub Tema 3 "Lingkungan dan Manfaatnya” untuk memperoleh materi pembelajaran yang akan dikembangkan pada LKPD (Lembar Kerja Peserta Didik) berbasis HOTS.

Tahap kedua yaitu desain. Dalam mengembangkan bahan ajar LKPD berbasis HOTS ada tahapantahapan untuk menghasilkan LKPD berbasis HOTS. Pertama, membuat bahan ajar LKPD berbasis HOTS di word. Kedua, mengubahnya dalam bentuk PDF (portable document format) diantaranya gambaran bahan ajarnya yaitu Cover (Sampul depan dan sampul belakang), kata pengantar, Daftar isi, Kompetensi inti, Kompetensi dasar, kegiatan pembelajaran, Metode HOTS, Evaluasi berbasis HOTS, dan Kunci jawaban. Sampul depan dan sampul belakang LKPD berbasis HOTS bertujuan untuk menampilkan atau mengarahkan isi yang ada dalam LKPD. Merupakan tujuan yang menggambarkan penelitian pengembangan bahan ajar LKPD berbasis HOTS dalam kata pengantar penelitian ini, peneliti sudah menjelaskan kenapa penelitian ini dikembangkan. Daftar isi merupakan arahan dalam bahan ajar. Kompetensi inti bertujuan untuk mengetahui pencapaian sikap peserta didik dalam proses pembelajaran. Kompetensi dasar bertujuan untuk pencapaian peserta didik dalam materi yang akan dikuasai pada proses pembelajaran. Pada kegiatan pembelajaran ini bertujuan untuk mencapai komepetensi dasar yang telah ditetapkan, dalam pengembangan LKPD berbasis HOTS terdapat 6 pembelajaran. Tahapan evaluasi merupakan untuk menguji pemahaman peserta didik pada materi yang telah diajarkan. Adapun desain LKPD berbasis HOTS disajikan pada gambar 2.
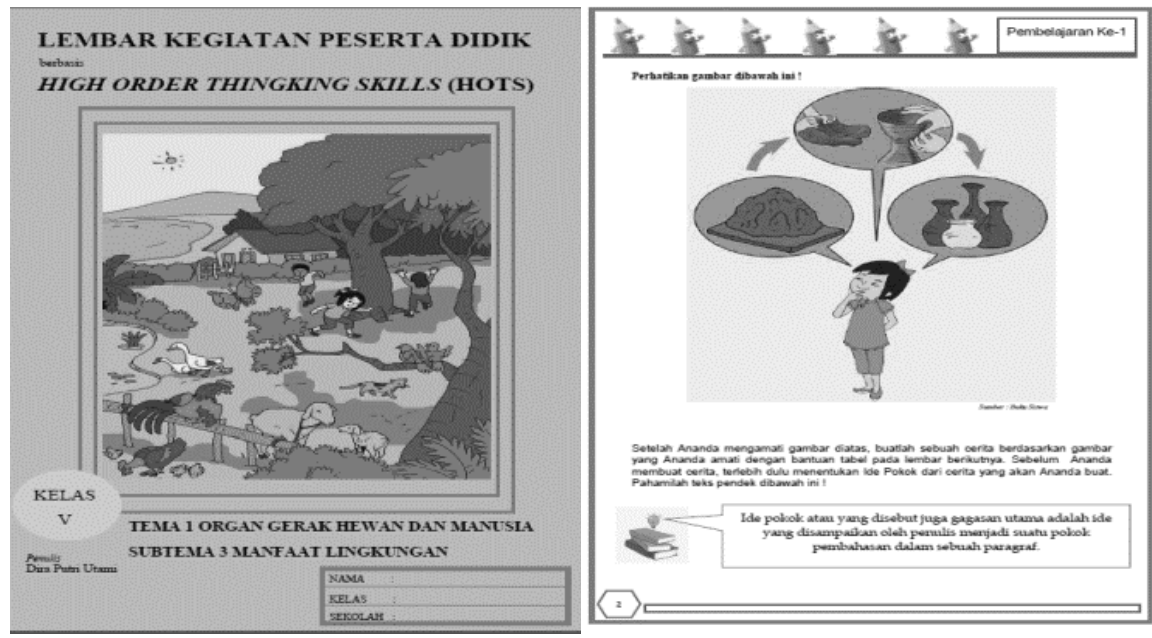

Gambar 2. Desain LKPD (Lembar Kerja Peserta Didik) berbasis HOTS (High Order Thinking Skills)

Tahap ketiga yaitu pengembangan. Tahap ini adalah mengembangkan LKPD berbasis HOTS. Adapun hasil pengembangan disajikan pada gambar 2. Setelah LKPD berhasil dikembangkan selanjutnya yaitu validasi produk. Validasi produk ini dilakukan dengan cara menghadirkan beberapa pakar atau tenaga ahli yang sudah berpengalaman untuk menilai bahan ajar ajar LKPD berbasis HOTS pada pembelajaran Tema 1 "Organ Gerak Hewan dan Manusia" Sub Tema 3 "Lingkungan dan Manfaatnya". Validasi yang pertama dilakukan yaitu Validasi desain dengan dua orang ahli dalam menilai desain. Berdasarkan hasil analisis data didapatkan bahwa rata-rata penilaian yang diberikan oleh ahli yaitu $91 \%$ sehingga mendapatkan kategori sangat layak. Selanjutnya dilakukan validasi materi dilakukan dengan dua orang ahli dalam menilai materi tematik. Hasil penilaian yang diberikan olara ahli yaitu ahli 1 (88\%) dan ahli kedua (83\%) sehingga rata-rata penilaian yang diberikan oleh para ahli yaitu 86\% sehingga LKPD yang dikembangkan mendapatkan kategori sangat layak. Validasi terakhir yaitu validasi bahasa yang dinilai oleh dua orang ahli dalam menilai pedoman umum ejaan bahasa indonesia (PUEBI). Hasil penilaian yaitu ahli 1 (90\%) dan ahli ke-2 (90\%) sehingga sehingga LKPD yang dikembangkan mendapatkan kategori sangat layak. Dapat disimpulkan bahwa LKPD berbasis HOTS ayak diterapkan pada siswa.

Tahap keempat yaitu implementasi. Setelah dilakukan validasi oleh ahli media, ahli materi, dan ahli bahasa selanjutnya dilakukan respon guru dan peserta didik yang terdiri dari satu orang guru dan sepuluh orang peserta didik kelas V. Adapun respon yang diberikan oleh guru disajikan pada Tabel 2. Tabel 2 menunjukan rata-rata yang diberikan guru kelas V sebesar 99\% sehingga memperoleh kategori "Sangat Menarik". Sejalan dengan pendapat guru yang menyampaikan bahwa bahan ajar LKPD (Lembar Kerja Peserta Didik) berbasis HOTS ini menarik perhatian peserta didik untuk belajar dan tingkat keinginan peserta didik belajar meningkat. Hasil uji coba lapangan skala terbatas yang melibatkan 10 
orang peserta didik menunjukkan hasil jumlah skor 130 dari skor maksimal pernyataan adalah 112 . Selanjutnya diketahui bahwa tanggapan peserta didik dari uji memperoleh rata-rata prentase penilaian sebesar 84\% dengan kriteria "Sangat Menarik".
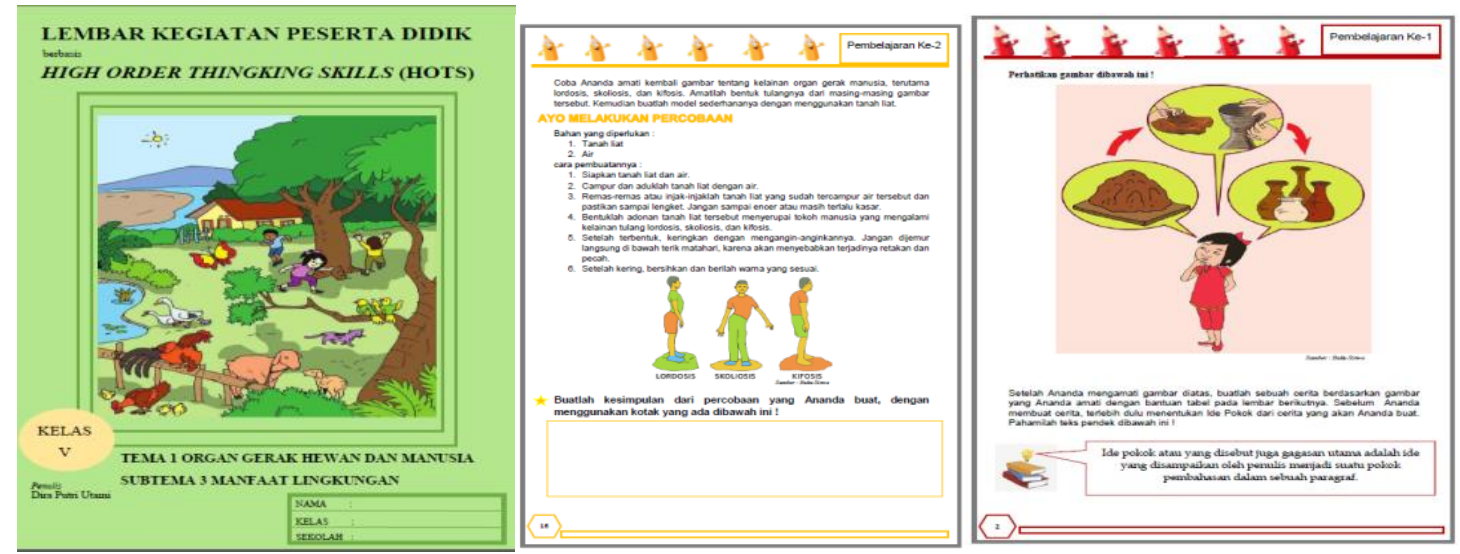

Gambar 2. LKPD (Lembar Kerja Peserta Didik) berbasis HOTS (High Order Thinking Skills)

Tabel 2. Respon Wali kelas $\mathrm{V}$

\begin{tabular}{llcc}
\hline No & Aspek Penilain & Wali Kelas V & Kategori \\
\hline 1 & Pengorganisasian Materi & $100 \%$ & Sangat Menarik \\
2 & Evaluasi dan Latihan Soal & $96 \%$ & Sangat Menarik \\
3 & Produk Bahan Ajar LKPD & $100 \%$ & Sangat Menarik \\
4 & Efek Bagi Pengguna & $100 \%$ & Sangat Menarik \\
\hline & Rata-Rata & $\mathbf{9 9 \%}$ & Sangat Menarik \\
\hline
\end{tabular}

\section{Pembahasan}

Dalam melaksanakan proses pembelajaran yang dilakukan guru dan siswa tidak terlepas dari penggunaan bahan ajar (Anisah \& Lastuti, 2018; Jazuli et al., 2018). Bahan ajar pada hakikatnya adalah isi dari mata pelajaran atau bidang studi yang diberikan kepada siswa sesuai dengan kurikulum yang digunakan (Baka et al., 2018; Martha \& Andini, 2019). Bahan ajar yang digunakan guru untuk menyampaikan materi kepada siswa, sehingga tujuan pembelajaran dapat tercapai dengan semestinya yang telah dirancang oleh guru (Hidayah \& Priscylio, 2019; Rostikawati \& Permanasari, 2016). Bahan ajar merupakan segala bahan (baik itu informasi, alat, maupun teks) yang disusun secara sistematis yang menampilkan sosok utuh dari kompetensi yang akan dikuasai oleh siswa dan digunakan dalam proses pembelajaran dengan tujuan untuk merencanakan dan penelaahan implementasi pembelajaran (Cahyadi, 2019; Gafur, 2010). Bahan ajar yang dikembangkan pada penelitian ini berbasis HOTS.

Setiap masalah yang akan dipecahkan oleh siswa menghasilkan sebuah kesempatan dalam memanfaatkan HOTS untuk pemahaman lebih mendalam (Harta et al., 2020; Ichsan et al., 2019; Zulfiani et al., 2020). Namun, hal ini tidak akan terjadi dengan sendirinya, guru harus memanfaatkan kesempatan ini untuk mendorong siswa dalam berfikir. LKPD (Lembar Kegiatan Peserta Didik) merupakan salah satu sarana untuk membantu dan mempermudah dalam kegiatan pembelajaran sehingga akan terbentuk interaksi yang efektif antara siswa dengan guru sehingga dapat meningkatkan aktifitas siswa dalam meningkatkan kemampuan berfikir (Diani, Nurhayati, 2019; Marshel \& Ratnawulan, 2020; Nurliawaty et al., 2017). Kemampuan memecahkan masalah yang ada dalam LKPD (Lembar Kegiatan Peserta Didik) tersebut yang akan mempengaruhi HOTS siswa (Anwar et al., 2020; Lu et al., 2021; Tanudjaya \& Doorman, 2020). Selain itu, HOTS akan terjadi ketika seseorang mengaitkan informasi baru dengan infromasi yang sudah tersimpan di dalam ingatannya dan mengaitkannya atau menata ulang serta mengembangkan informasi tersebut untuk mencapai suatu tujuan atau menemukan suatu penyelesaian dari suatu keadaan yang sulit dipecahkan ( Rahmawati, Nisfah, 2019; Sari et al., 2020).

LKPD yang dikembangkan dalam penelitian ini layak diterapkan dalam proses pembelajaran karena bahan ajar ini inovatif sehingga merangsang siswa dalam belajar. LKDP (Lembar Kegiatan Peserta Didik) berbasis HOST ada saat diterapkan terdapat peningkatan hasil belajar siswa, dan ketertarikan siswa dalam mengikuti proses pembealajaran yang berlansung. Pada saat peneliti menjelakan materi pembelajaran dengan menggunakan LKPD (Lembar Kerja Peserta Didik) berbasis, peserta didik kegirangan melihat bahan ajar, sehingga mereka bersemangat untuk ingin mengetahui lebih lanjut materi 
pembelajaran, dan membangkitkan minat rasa ingin tahunya melalui bertanya jawab mengenai materi yang sedang dipelajarinya. Dapat disimpulkan bahwa bahan ajar menarik akan meningkatkan motivasi siswa dalam belajar (Arsanti, 2018; Gunada et al., 2017; Susilowati et al., 2018). Temuan penelitian sebelumnya juga menyatakan bahwa LKPD inovatif dapat membantu siswa dalam belajar (Marshel \& Ratnawulan, 2020; Nurliawaty et al., 2017). Dapat disimpulkan bahwa LKPD dapat memudahkan siswa dalam belajar. Implikasi penelitian ini yaitu LKPD berbasis HOTS yang dikembangkan layak diterapkan dalam proses pembelajaran sehingga dapat membantu siswa dalam belajar

\section{SIMPULAN}

Kualitas LKPD (Lembar Kerja Peserta Didik) berbasis HOTS (High Order Thingking Skills) telah mencapai standart kelayakan pembelajaran dari hasil penilaian yang diperoleh dari ahli desain, ahli bahasa, ahli materi, respon guru dan peserta didik. Dapat disimpulkan bahwa LKPD (Lembar Kerja Peserta Didik) berbasis HOTS (High Order Thingking Skills) dapat diterapkan dalam pembelajaran dan dapat meningkatkan minat siswa dalam belajar.

\section{DAFTAR PUSTAKA}

Afrita, M., \& Darussyamsu, R. (2020). Validitas Instrumen Tes Berpikir Tingkat Tinggi (HOTS) pada Materi Sistem Respirasi di Kelas XI SMA. Jurnal Mangifera Edu, 4(2). https://doi.org/10.31943/mangiferaedu.v4i2.83.

Akib, E., Imran, M. E., Mahtari, S., Mahmud, R. M., Prawiyogy, A. G., Supriatna, I., \& Ikhsan, M. H. (2020). Study on Implementation of Integrated Curriculum in Indonesia. IJORER : International Journal of Recent Educational Education, 1(1), 39-57. https://doi.org/10.46245/ijorer.v1i1.24.

Amali, L. N., Zees, N., \& Suhada, S. (2020). Motion Graphic Animation Video As Alternative Learning Media. Jambura Journal of Informatics, 2(1). https://doi.org/10.37905/jji.v2i1.4640.

Andani, M. (2020). E-Modul Fisika Dasar I Berbasis 3D Pageflip Professional. Schrodinger Journal of Physics Education, 1(2), 44-47. https://doi.org/10.37251/sjpe.v1i2.79.

Andoko. (2020). Peningkatan Hots Dan Prestasi Belajar Melalui Metode Inkuiri Kelas 7C SMPN 1 Wonosobo Tahun Pelajaran 2018/2019. Spektra: Jurnal Kajian Pendidikan Sains, 6(1). https://doi.org/10.32699/spektra.v6i1.134.

Ani Rahmawati, Nur Lailatin Nisfah, S. K. (2019). The Capability Analysis of High Order Thinking Skills (HOTS) on Dynamic Electricity Material in Junior High School. JPPPF: Jurnal Penelitian Dan Pengembangan Pendidikan Fisika, 5(3). https://doi.org/10.21009/1.05211.

Anisah, \& Lastuti, S. (2018). Pengembangan Bahan Ajar berbasis HOTS untuk Meningkatkan Kemampuan Pemecahan Masalah Matematis Mahasiswa. Kreano: Jurnal Matematika Kreatif-Inovatif, 9(2), 191197. https://doi.org/10.15294/kreano.v9i2.16341.

Anwar, Y., Selamet, A., Huzaifah, S., \& Madang, K. (2020). Training in developing higher-order thinking based online test instrument for biology teachers in Sekayu City. Journal of Community Service and Empowerment, 1(3), 150-155. https://doi.org/10.22219/jcse.v1i3.12241.

Arsanti, M. (2018). Pengembangan Bahan Ajar Mata Kuliah Penulisan Kreatif Bermuatan Nilai-Nilai Pendidikan Karakter Religius Bagi Mahasiswa Prodi Pbsi, Fkip, Unissula. KREDO : Jurnal Ilmiah Bahasa Dan Sastra, 1(2), 71-90. https://doi.org/10.24176/kredo.v1i2.2107.

Astiningtyas, A. (2018). Kesiapan Guru Sekolah Dasar Dalam Pelaksanaan Pembelajaran Tematik Integratif Pada Kurikulum 2013. Primary: Jurnal Pendidikan Guru Sekolah Dasar, 7(1), 60. https://doi.org/10.33578/jpfkip.v7i1.5340.

Baka, T. ., Laksana, D. N. ., \& Dhiu, K. . (2018). Konten dan Konteks Budaya Lokal Ngada sebagai Bahan Ajar Tematik di Sekolah Dasar. Journal of Education Technology, 2(2), 46-55. https: //doi.org/10.23887/jet.v2i2.16181.

Bui, V. H., \& Do Van Dung. (2019). Development of Vietnamese Vocational Education Teachers to adapt the Industrial Revolution 4.0. Asian Journal of Interdisciplinary Research, 2(4), 1-7. https://doi.org/10.34256/ajir1941.

Cahyadi, R. A. H. (2019). Pengembangan Bahan Ajar Berbasis Addie Model. Halaqa: Islamic Education Journal, 3(1), 35. https://doi.org/10.21070/halaqa.v3i1.2124.

Cintia, N. I., Kristin, F., \& Anugraheni, I. (2018). Penerapan Model Pembelajaran Discovery Learning Untuk Meningkatkan Kemampuan Berpikir Kreatif Dan Hasil Belajar Siswa. Perspektif Ilmu Pendidikan. https://doi.org/10.21009/pip.321.8.

Dewi, C. (2017). Peningkatan Keterampilan Berbicara Dalam Bermain Drama Melalui Model Pembelajaran Kooperatif Tipe Inside-Outside Circle. JINoP (Jurnal Inovasi Pembelajaran), 3(2), 567-575. 
https://doi.org/10.22219/jinop.v3i2.4575.

Dini Rahma Diani, Nurhayati, D. S. (2019). Pengembangan Lembar Kerja Peserta Didik (LKPD) Menulis Cerpen Berbasis Aplikasi Android. Jurnal Bahasa, Sastra, Dan Pengajarannya, 7, 2. https://doi.org/10.20961/basastra.v7i2.37800.

Gafur, A. (2010). Konsep, Prinsip, dan Prosedur Pengembangan Modul Sebagai Bahan Ajar. Jurnal Civics Media Kajian Kewarganegaraan, 7(1). https://doi.org/10.21831/civics.v7i1.3445.

Gunada, I. W., Rokhmat, J., Hikmawati, H., \& Kesipudin, K. (2017). Pengembangan Bahan Ajar Kompilasi Fisika Matematika Ii Pokok Bahasan Persamaaan Diferensial Untuk Meningkatkan Penalaran Matematis. Jurnal Pendidikan Fisika Dan Teknologi, 3(2), 216. https://doi.org/10.29303/jpft.v3i2.414.

Harta, J., Rasuh, N. T., \& Seriang, A. (2020). Using HOTS-Based Chemistry National Exam Questions to Map the Analytical Abilities of Senior High School Students. Journal of Science Learning, 3(3), 143-148. https://doi.org/10.17509/jsl.v3i3.22387.

Hendawi, M., \& Nosair, M. R. (2020). Students' technological awareness at the College of Education, Qatar University. Cypriot Journal of Educational Sciences, 15(4), 749-765. https://doi.org/10.18844/cjes.v15i4.5057.

Hidayah, D. N., \& Priscylio, G. (2019). Pengembangan Bahan Ajar Mandiri Pokok Bahasan Suhu dan Kalor Menggunakan Software Camtasia. Journal of Teaching and Learning Physics, 4(1), 50-64. https://doi.org/10.15575/jotalp.v4i1.4093.

Hidayat, W., \& Andriani, A. (2020). Pelaksanaan Penilaian Autentik Guru Pendidikan Anak Usia Dini. Cakrawala Dini: Jurnal Pendidikan Anak Usia Dini, 12(2). https://doi.org/10.17509/cd.v11i2.24922.

Husnah, M. (2017). Hubungan Tingkat Berpikir Kritis Terhadap Hasil Belajar Fisika Siswa Dengan Menerapkan Model Pembelajaran Problem Based Learning. Journal of Physics and Science Learning (PASCAL), 01(2), 10-17. https://doi.org/10.1088/1742-6596/1157/3/032009.

Ichsan, I. Z., Sigit, D. V., Miarsyah, M., Ali, A., Arif, W. P., \& Prayitno, T. A. (2019). HOTS-AEP: Higher order thinking skills from elementary to master students in environmental learning. European Journal of Educational Research, 8(4), 935-942. https://doi.org/10.12973/eu-jer.8.4.935.

Indrianingrum, R., Mahardika, Ik., Wahyuni, D., a, S., a, I., \& Hariyadi, S. (2018). Effectiveness of Stem-Based Science Student Worksheet in Improving Multiple Representation Ability of Junior High School Students. International Journal of Advanced Research, 6(4), 1366-1369. https://doi.org/10.21474/ijar01/6995.

Jazuli, M., Azizah, L. F., \& Meita, N. M. (2018). Pengembangan Bahan Ajar Elektronik Berbasis Android Sebagai Media Interaktif. LENSA (Lentera Sains): Jurnal Pendidikan IPA, 7(2), 47-65. https://doi.org/10.24929/lensa.v7i2.22.

Jing, S., Tang, Y., Liu, X., \& Gong, X. (2020). A Learner Model Integrating Cognitive and Metacognitive and Its Application on Scratch Programming Projects. IFAC-PapersOnLine, 53(5), 644-649. https://doi.org/10.1016/j.ifacol.2021.04.154.

Junedi, B., Mahuda, I., \& Kusuma, J. W. (2020). Optimalisasi keterampilan pembelajaran abad 21 dalam proses pembelajaran pada Guru MTs Massaratul Mut'allimin Banten. Transformasi: Jurnal Pengabdian Masyarakat, 16(1), 63-72. https://doi.org/10.20414/transformasi.v16i1.1963.

Khamzawi, S., \& Wiyono, K. (2015). Pengembangan Multimedia Interaktif Berbasis Model Pembelajaran Problem Based Leaning Pada Mata Pelajaran Fisika Pokok Bahasan Fuida Dinamis Untuk SMA Kelas XI. Jurnal Inovasi Dan Pembelajaran Fisika, 2(1), 100-108. https://doi.org/10.36706/jipf.v2i1.259.4

Kidd, D., Miner, J., Schein, M., Blauw, M., \& Allen, D. (2020). Ethics across the curriculum: Detecting and describing emergent trends in ethics education. Studies in Educational Evaluation, 67. https://doi.org/10.1016/j.stueduc.2020.100914.

Kusumaningtyas, A., \& Setyawafi, E. (2015). Teacher performance of the state vocational high school teachers in Surabaya. International Journal of Evaluation and Research in Education (IJERE), 4(2), 76-83. https://doi.org/10.11591/ijere.v4i2.4495.

Lewis, M., \& Ponzio, V. (2016). Character Education As the Primary Purpose of Schooling for the Future. Jurnal Ilmiah Peuradeun, 4(2), 137. https://doi.org/10.26811/peuradeun.v4i2.92.

Lu, K., Yang, H. H., Shi, Y., \& Wang, X. (2021). Examining the key influencing factors on college students ' higher - order thinking skills in the smart classroom environment. Int J Educ Technol High Educ, 18(1), 1-13. https: //doi.org/10.1186/s41239-020-00238-7.

Marshel, J., \& Ratnawulan. (2020). Analysis of Students Worksheet (LKPD) integrated science with the theme of the motion in life using integrated connected type 21st century learning. Journal of Physics: Conference Series, 1481(1). https://doi.org/10.22219/jppg.v1i1.12462. 
Martha, nia ulfa, \& Andini, novita pri. (2019). Pengembangan Bahan Ajar Mata Pelajaran Bahasa Indonesia Berbasis Cerita Rakyat Kabupaten Banjarnegara. Jurnal Inovasi Pembelajaran, 5(2). https://doi.org/10.22219/jinop.v5i2.9992.

Nikmah, S., Nuroso, H., \& Reffiane, F. (2019). Pengaruh Model Pembelajaran Terpadu Tipe Shared Berbantu Media Pop- Up Book Terhadap Hasil Belajar. Jurnal Pedagogi Dan Pembelajaran, 2(2), 264. https://doi.org/10.23887/jp2.v2i2.17920.

Ningsih, S. Y., \& Mahyuddin, N. (2021). Desain E-Module Tematik Berbasis Kesantunan Berbahasa Anak Usia Dini di Taman Kanak-Kanak. Jurnal Obsesi : Jurnal Pendidikan Anak Usia Dini, 6(1), 137-149. https://doi.org/10.31004/obsesi.v6i1.1217.

Nurliawaty, L., Mujasam, M., Yusuf, I., \& Widyaningsih, S. W. (2017). Lembar Kerja Peserta Didik (LKPD) Berbasis Problem Solving Polya. JPI (Jurnal Pendidikan Indonesia), 6(1), 72-81. https://doi.org/10.23887/jpi-undiksha.v6i1.9183.

Nurmala, \& Mucti, A. (2019). Efektivitas Penggunaan LKM Berbasis HOTS (Higher Order Thinking Skills) Terhadap Hasil Belajar Mahasiswa Pendidikan Matematika. Journal of Hanoi Math, 2(2). https://doi.org/10.30862/jhm.v2i2.67.

Pentury, H., Festiyed, Hamdi, \& Yurnetti. (2019). Pembuatan Lembar Kerja Peserta Didik (LKPD) Berbasis Model Discovery Learning Pada Materi Gelombang Berbantuan Aplikasi Android Untuk Kelas XI SMA/MA. Pillar of Physics Education, 12(4), 617-624. https://doi.org/10.24036/7144171074.

Pramana, M. W. A., Jampel, I. N., \& Pudjawan, K. (2020). Meningkatkan Hasil Belajar Biologi Melalui EModul Berbasis Problem Based Learning. Jurnal Edutech Undiksha, 8(2), 17. https://doi.org/10.23887/jeu.v8i2.28921.

Prastikawati, E. F., Wiyaka, W., \& Budiman, T. C. S. (2021). Pelatihan Penyusunan Soal Bahasa Inggris Berbasis HOTS bagi Guru Bahasa Inggris SMP. Jurnal Pengabdian Masyarakat, 6(1). https://doi.org/10.30653/002.202161.761.

Pratama, G. S., \& Retnawati, H. (2018). Urgency of Higher Order Thinking Skills (HOTS) Content Analysis in Mathematics Textbook. Journal of Physics: Conference Series, 1097(1). https://doi.org/10.1088/1742-6596/1097/1/012147.

Putranta, H., \& Supahar. (2019). Synthesis of the Cognitive Aspects' Science Literacy and Higher Order Thinking Skills (HOTS) in Chapter Momentum and Impulse. Journal of Physics: Conference Series, 1397(1). https://doi.org/10.1088/1742-6596/1397/1/012014.

Putri, I. A. A. K., Pudjawan, \& Suditha, I. W. R. (2013). Pengaruh Model Pembelajaran Master Terhadap Kemampuan Berpikir Kritis Siswa Kelas V SD 1 Banyuning Kecamatan Buleleng. Mimbar PGSD Undiksha, 1(1). https://doi.org/10.23887/jjpgsd.v1i1.848.

Ridwan. (2016). Dasar-Dasar Statistika (Alfabeta).

Rostikawati, D. A., \& Permanasari, A. (2016). Rekonstruksi Bahan Ajar Dengan Konteks Socio-Scientific Issues Pada Materi Zat Aditif Makanan Untuk Meningkatkan Literasi Sains Siswa. Jurnal Inovasi Pendidikan IPA, 2(2), 156-164. https://doi.org/10.21831/jipi.v2i2.8814.

Ruengtam, P. (2013). Modeling of Cooperative/Collaborative Learning Technique: A Case Study of Interior Architectural Program. Procedia - Social and Behavioral Sciences, 105. https://doi.org/10.1016/j.sbspro.2013.11.038.

Rusydiyah, E. F., Indrawati, D., Jazil, S., Susilawati, \& Gusniwati. (2021). Stem learning environment: Perceptions and implementation skills in prospective science teachers. Jurnal Pendidikan IPA Indonesia, 10(1), 138-148. https://doi.org/10.15294/jpii.v10i1.28303.

Sagala, P. N., \& Andriani, A. (2019). Development of Higher-Order Thinking Skills (HOTS) Questions of Probability Theory Subject Based on Bloom's Taxonomy. Journal of Physics: Conference Series, 1188(1). https://doi.org/10.1088/1742-6596/1188/1/012025.

Saifullah, A. (2018). Penerapan Model Project Based Learning Untuk Mengembangkan Soft Skills Dan Kualitas Hasil Belajar Siswa Pada Pembelajaran Pendidikan Agama Islam (PAI) dI SMA Avicenna Cinere. Jurnal Pendidikan Kewarganegaraan, https://doi.org/10.32493/jpkn.v5i2.y2018.p137-150.

Sari, A. N., Wahyuni, R., \& Rosmaiyadi, R. (2016). Penerapan Pendekatan Open-Ended untuk Meningkatkan Kemampuan Berpikir Kritis Siswa Pada Materi Aljabar Kelas VIII SMP Negeri 10 Pemangkat. JPMI (Jurnal Pendidikan Matematika Indonesia), 1(1), 20. https://doi.org/10.26737/jpmi.v1i1.78.

Sari, Hindun, Mahmudati, Miharja, \& Fauzi. (2020). Are Male and Female Students Different in High-Order Thinking Skills? Jurnal Pendidikan Indonesia, 9(1), 42-48. https://doi.org/10.23887/jpiundiksha.v9i1.17575.

Silalahi, M. V. (2020). Development of E-Modules Based on Exe-Learning on Topics of Reaction Rate Against Student Learning Outcomes Mechanical Engineering. International Journal of Education and Curriculum Application, 3(2), 114-120. https://doi.org/10.31764/ijeca.v3i2.2672. 
Suantara, I. K. T., Ganing, N. N., Agung, I. G., \& Wulandari, A. (2019). Pengaruh Model Pembelajaran Think Pair Share Berbantuan Media TTS terhadap Kompetensi Pengetahuan IPA. Jurnal Ilmiah Sekolah Dasar, 3(4), 473-480. https://doi.org/10.23887/jisd.v3i4.21783.

Sulistiono, A. A. (2014). Kebugaran Jasmani Siswa Pendidikan Dasar dan Menengah di Jawa Barat. Jurnal Pendidikan Dan Kebudayaan, 20(2), 223. https://doi.org/10.24832/jpnk.v20i2.140.

Supriyanto, A., Hartini, S., Irdasari, W. N., Miftahul, A., Oktapiana, S., \& Mumpuni, S. D. (2020). Teacher professional quality: Counselling services with technology in Pandemic Covid-19. Counsellia: Jurnal Bimbingan Dan Konseling, 10(2), 176. https://doi.org/10.25273/counsellia.v10i2.7768.

Suryawati, E., Suzanti, F., Zulfarina, Putriana, A. R., \& Febrianti, L. (2020). The implementation of local environmental problem-based learning student worksheets to strengthen environmental literacy. Jurnal Pendidikan IPA Indonesia, 9(2), 169-178. https://doi.org/10.15294/jpii.v9i2.22892.

Susanti, N., Yennita, Y., \& Azhar, A. (2020). Development of Contextual Based Electronic Global Warming Modules Using Flipbook Applications as Physics Learning Media in High Schools. Journal of Educational Sciences, 4(3), 541. https://doi.org/10.31258/jes.4.3.p.541-559.

Susilowati, S., Sajidan, S., \& Ramli, M. (2018). Keefektifan perangkat pembelajaran berbasis inquiry lesson untuk meningkatkan keterampilan berpikir kritis siswa. Jurnal Penelitian Dan Evaluasi Pendidikan, 22(1), 49-60. https://doi.org/10.21831/pep.v22i1.17836.

Tanudjaya, C. P., \& Doorman, M. (2020). Examining higher order thinking in Indonesian lower secondary mathematics classrooms. Journal on Mathematics Education, 11(2), 277-300. https: //doi.org/10.22342/jme.11.2.11000.277-300.

Tempelaar, D. (2019). Assessment \& Evaluation in Higher Education Supporting the less-adaptive student: The role of learning analytics, formative assessment and blended learning. Assessment and Evaluation in Higher Education, 45(4). https: //doi.org/10.1080/02602938.2019.1677855.

Trianggono, M. M. (2017). Analisis Kausalitas Pemahaman Konsep Dengan Kemampuan Berpikir Kreatif Siswa Pada Pemecahan Masalah Fisika. Jurnal Pendidikan Fisika Dan Keilmuan (JPFK), 3(1), 1. https://doi.org/10.25273/jpfk.v3i1.874.

Uerz, D., Volman, M., \& Kral, M. (2018). Teacher educators' competences in fostering student teachers' proficiency in teaching and learning with technology: An overview of relevant research literature. Teaching and Teacher Education, 70, 12-23. https://doi.org/10.1016/j.tate.2017.11.005.

Wulandari, Sudatha, \& Simamora. (2020). Pengembangan Pembelajaran Blended Pada Mata Kuliah Ahara Yoga Semester II di IHDN Denpasar. Jurnal Edutech Undiksha, 8(1), 1-15. https://doi.org/10.23887/jeu.v8i1.26459.

Yuliani, T., Noer, S. H., \& Rosidin, U. (2018). Guided Discovery Worksheet for Increasing Mathematical Creative Thinking and Self-Efficacy. International Journal of Trends in Mathematics Education Research, 1(2), 30-34. https://doi.org/10.33122/ijtmer.v1i1.6.

Yulianto, A., Fatchan, A., \& Astina, I. K. (2017). Penerapan Model Pembelajaran Project Based Learning Berbasis Lesson Study Untuk Meningkatkan Keaktifan Belajar Siswa. Jurnal Pendidikan, 2(3), 448453. https://doi.org/10.17977/jptpp.v2i3.8729.

Yustina, \& Kapsin. (2017). The implementation of constructivism-based student worksheets within the theme 'the prevention of land and forest fire' in science education for seventh graders in Riau. Jurnal Pendidikan IPA Indonesia, 6(2), 298-305. https: //doi.org/10.15294/jpii.v6i2.10573.

Zulfiani, Suwarna, I. P., \& Sumantri, M. F. (2020). Science adaptive assessment tool: Kolb's learning style profile and student's higher order thinking skill level. Jurnal Pendidikan IPA Indonesia, 9(2), 194207. https://doi.org/10.15294/jpii.v9i2.23840. 